\title{
Benign osteoblastoma of ethmoid and sphenoid sinus: a rare presentation
}

\author{
Etmoid ve sfenoid sinüs benign osteoblastoması: Nadir bir olgu \\ Özgür Kemal, ${ }^{1}$ Selami Yavuz, ${ }^{2}$ Gülten Taşkın ${ }^{3}$ \\ ${ }^{1}$ Department of Otolaryngology, Medical Faculty of Ondokuz Mayıs University, Samsun, Turkey \\ ${ }^{2}$ Department of Otolaryngology, Samsun Medicana Hospital, Samsun, Turkey \\ ${ }^{3}$ Department of Radiology, Samsun Medicana Hospital, Samsun, Turkey
}

\begin{abstract}
Benign osteoblastoma is a rare tumor of bone, usually confined to the long bones and vertebrae. Its occurrence in the paranasal sinuses is extremely rare. In this article, we report a 31-year-old male patient with benign osteoblastoma in sphenoethmoid region. A pathological mass was detected on axial and coronal plane in computed tomography imaging of the paranasal sinus. The tumor was excised and the pathological diagnosis was reported as benign osteoblastoma. In this article, a rare location of osteoblastoma and its treatment is described.
\end{abstract}

Keywords: Ethmoid sinus, osteoblastoma, sphenoid sinus.

Benign osteoblastoma was first described in 1956 by Lichtenstein $^{[1]}$ and Jaffe. ${ }^{[2]}$ Histologically, it comprises approximately $1 \%$ of all primary bone tumors and usually occurs in the long bones and vertebrae (60\%). ${ }^{[3]}$ The male/female ratio has been reported as 2 , and it is most often seen in the second decade of life. ${ }^{[3]}$ Benign osteoblastoma consists of hypocellular mineralized tissue that may form large masses and ir regular trabeculae. This mineralized matrix contains osteoblasts and occasional osteoclasts such as giant cells in a richly vascular fibrous stroma ${ }^{[4]}$ Although head and neck involvement is rare, the temporal bone is the most common area of benign osteoblastoma in the head and neck. ${ }^{[5]}$ This is a case of benign osteoblastoma in the left ethmoid and sphenoid region.
$\ddot{O} Z$

Benign osteoblastoma sıklıkla uzun kemikleri ve vertebraları tutan nadir bir kemik tümörüdür. Paranazal sinüs tutulumu son derece nadirdir. Bu makalede, sfenoetmoid bölgede benign osteoblastoması olan 31 yaşında bir erkek hasta sunuldu. Paranazal sinüsün bilgisayarlı tomografisinde aksiyal ve koronal planda patolojik kitle saptandı. Tümör eksize edildi ve patolojik tanı benign osteoblastoma olarak bildirildi. $\mathrm{Bu}$ makalede, nadir bir osteoblastoma tutulum yeri ve tedavisi anlatıld..

Anahtar sözcükler: Etmoid sinüs, osteoblastoma, sfenoid sinüs.

\section{CASE REPORT}

A 31-year-old male patient presented with complaints of headache, nasal obstruction, and left retro-orbital pain, which had been ongoing for one year. Despite previous medical treatments that were detailed in his records, the complaints had worsened. On physical examination, no signs of nasal congestion, nasal dripping or epistaxis were observed. However, endoscopic examination showed a suspicious swelling just posterior to the lamina papyracea.

A pathological mass was determined on axial and coronal plane computed tomography (CT) imaging of the paranasal sinuses. The lesion was $15 \times 30 \mathrm{~mm}$ and 


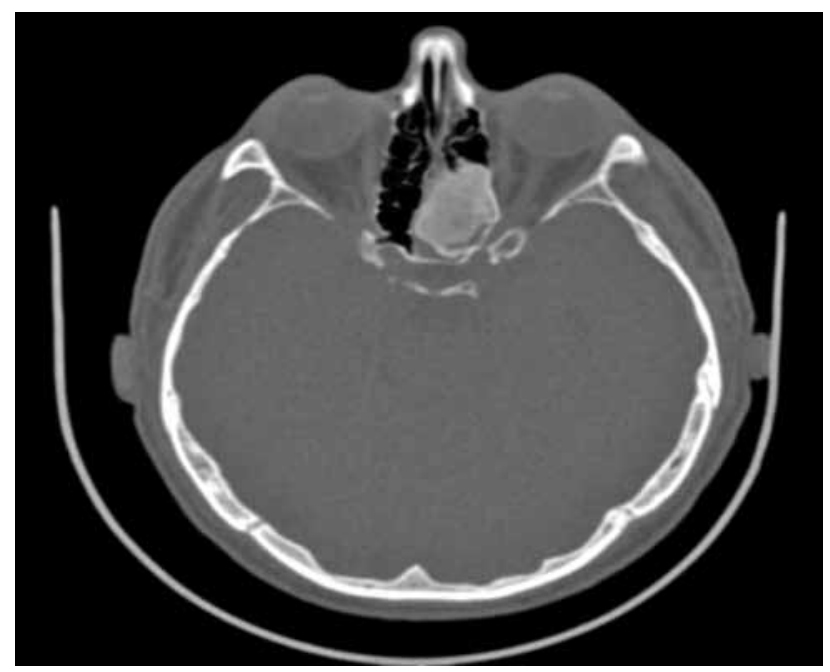

Figure 1. Axial computed tomography view of the osteoma in the sphenoid sinus.

involved the anterosuperior sphenoid sinus, ethmoid sinus and orbital medial wall (Figure 1-3). The mass had a close relationship with the optic nerve and orbit. That is why we used a navigation system.

Under general anesthesia, endoscopic sinus surgery with navigation (Fiagon Navigation System, Germany) was performed and the bony mass was removed with attention paid to the orbit, optic nerve and internal carotid artery.

After removing the mass, the patient's complaints decreased dramatically. Informed consent was obtained from the patient for publication of this case report and images.

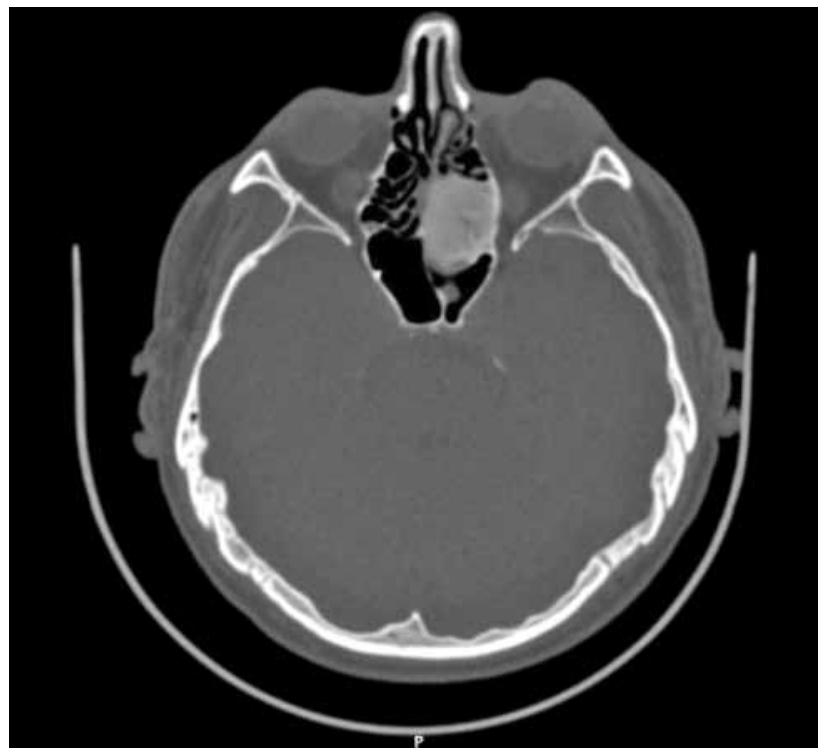

Figure 2. Axial computed tomography view of the osteoma in the ethmoid region.

\section{DISCUSSION}

Benign osteoblastoma is a rare primary neoplasm of the bone that can be seen in any place in the skeleton. Male gender is a predisposing factor and those aged between 10 and 35 years are at greater risk. ${ }^{[6]}$

Benign osteoblastoma typically affects the long bones and vertebrae with extremely rare cases of head and neck involvement. In a clinicopathological study of 360 cases, only 11 cases (4\%) were located in the head and neck. ${ }^{[7]}$ The most common presenting symptom of osteoblastomas are pain in the vertebra and long bones and the most common symptoms in the head and neck region are nasal obstruction, headache, proptosis and visual problems. ${ }^{[8]}$ Osteoblastomas are usually wellcircumscribed masses. ${ }^{[9,10]}$ The tumor usually shows radiolucent deficits with varying degrees of calcification.

Treatment by limited local resection is recommended because of the benign nature, so local excision and curettage should be adequate. ${ }^{[10]}$ In the current case, the patient had suffered from headaches, retro-orbital pain and nasal obstruction for a year. Paranasal CT findings showed the osteoblastoma, so endoscopic sinus surgery was applied to the patient. The mass was very closely involved with the orbital medial wall as well as the optic nerve, which was the reason for utilizing the navigation system in this case. All gross tumor was resected without any macroscopic residual (Figure 4). ${ }^{[1]}$

In the differential diagnosis of osteoid lesions orginating from the paranasal sinuses, osteoid osteoma, aneurysmal bone cyst, giant cell tumor of the bone, osteosarcoma and osteoma with osteoblastoma-like features should be considered. Osteomas are the most frequently encountered bony tumor of the paranasal

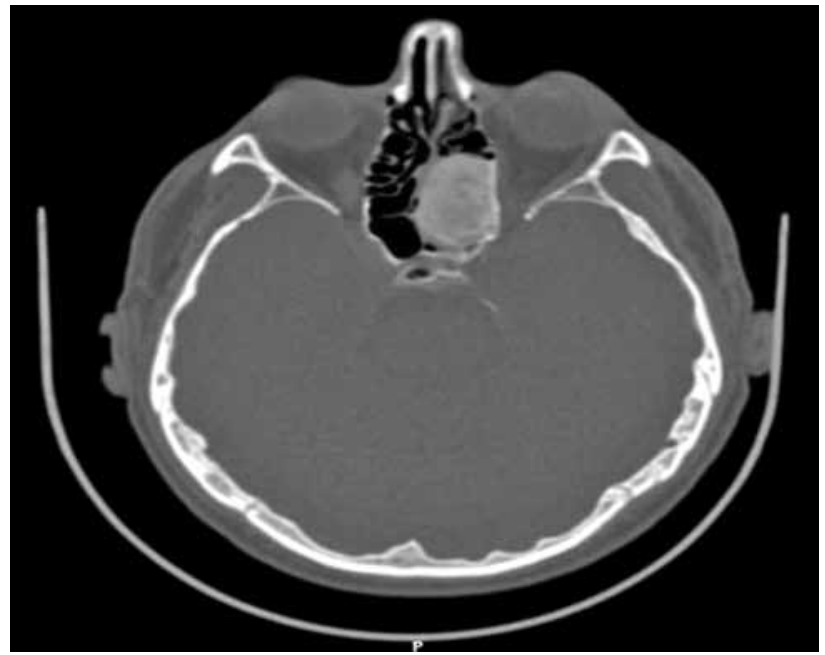

Figure 3. Axial computed tomography view of the osteoma, with the optic nerve passing just lateral to it. 

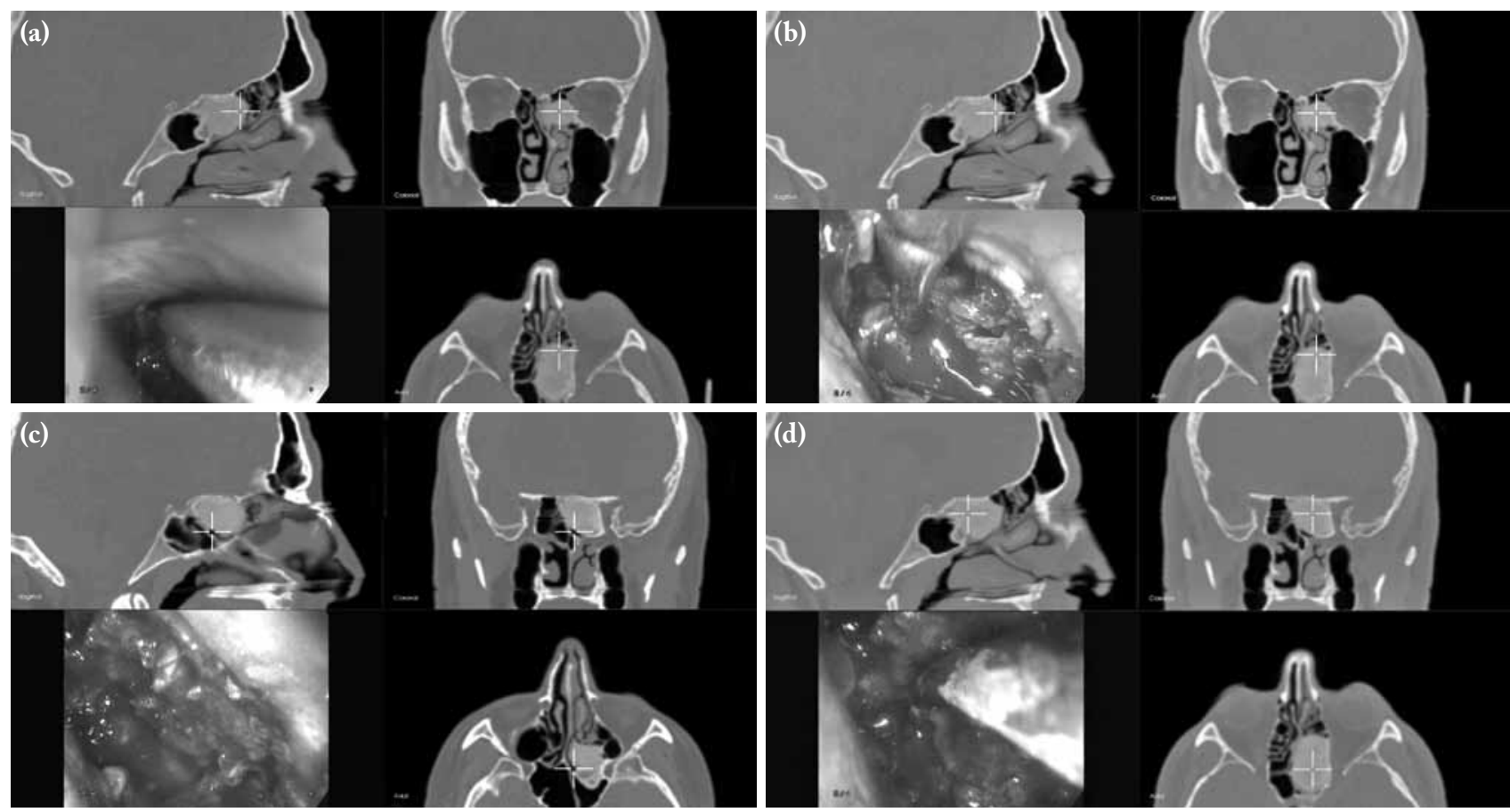

Figure 4. Navigation views of the osteoma during surgery. $(\mathbf{a}, \mathbf{b})$ The anterior part of the osteoblastoma. (c) The inferiomedial part of the osteoblastoma. (d) Approaching to the skull base during surgery.

sinuses and consist of mature compact, trabecular bone, usually growing in the paranasal sinuses. ${ }^{[12-14]}$ In the current case the histologically pathognomonic findings were the islands of osteoid tissues of different sizes formed by osteoblasts, and varying degrees of calcification in a well vascularized stroma. The intertrabecular tissue contained loose fibrovascular tissue and few osteoclasttype giant cells.

The recurrence rate of benign osteoblastoma has been reported as $10 \%$ with the most common cause of recurrence being incomplete partial resection or incomplete local curettage.

\section{Conclusion}

This patient presented with a huge osteoblastoma in the paranasal sinuses. These kinds of tumors are rare in the paranasal sinuses and can be resected with an endoscopic approach, which will avoid scar tissue in such cases. Osteoblastoma should be kept in mind on presentation of osteoid lesions in the paranasal sinuses.

\section{Declaration of conflicting interests}

The authors declared no conflicts of interest with respect to the authorship and/or publication of this article.

\section{Funding}

The authors received no financial support for the research and/or authorship of this article.

\section{REFERENCES}

1. Lichtenstein L. Benign osteoblastoma; a category of osteoid-and bone-forming tumors other than classical osteoid osteoma, which may be mistaken for giant-cell tumor or osteogenic sarcoma. Cancer 1956;9:1044-52.

2. Jaffe HL. Benign osteoblastoma. Bull Hosp Joint Dis 1956;17:141-51.

3. Bilkay U, Erdem O, Ozek C, Helvaci E, Kilic K, Ertan $\mathrm{Y}$, et al. A rare location of benign osteoblastoma: review of the literature and report of a case. J Craniofac Surg 2004;15:222-5.

4. Caltabiano R, Serra A, Bonfiglio M, Platania N, Albanese V, Lanzafame S, et al. A rare location of benign osteoblastoma: case study and a review of the literature. Eur Rev Med Pharmacol Sci 2012;16:1891-4.

5. Lu ZH, Cao WH, Qian WX. Aggressive osteoblastoma of the temporal bone: a case report and review of the literature. Clin Imaging 2013;37:386-9.

6. Kukwa W, Oziębło A, Oecińska A, Czarnecka AM, Włodarski K, Kukwa A. Aggressive osteoblastoma of the sphenoid bone. Oncol Lett 2010;1:367-371.

7. Lucas DR, Unni KK, McLeod RA, O'Connor MI, Sim FH. Osteoblastoma: clinicopathologic study of 306 cases. Hum Pathol 1994;25:117-34.

8. Patel AA, Friedel ME, Liu JK, Eloy JA. Endoscopic endonasal resection of extensive anterior skull base sinonasal osteoblastoma. Otolaryngol Head Neck Surg 2012;147:594-6.

9. Park YK, Kim EJ, Kim SW. Osteoblastoma of the ethmoid sinus. Skeletal Radiol 2007;36:463-7. 
10. Lehmer LM, Kissel P, Ragsdale BD. Frontal sinus osteoma with osteoblastoma-like histology and associated intracranial pneumatocele. Head Neck Pathol 2012;6:384-8.

11. Lübbers HT, Jacobsen C, Könü D, Matthews F, Grätz KW, Obwegeser JA. Surgical navigation in cranio-maxillofacial surgery: an evaluation on a child with a cranio-facio-orbital tumour. Br J Oral Maxillofac Surg 2011;49:532-7.

12. McHugh JB, Mukherji SK, Lucas DR. Sino-orbital osteoma: a clinicopathologic study of 45 surgically treated cases with emphasis on tumors with osteoblastoma-like features. Arch Pathol Lab Med 2009;133:1587-93.

13. Matsumoto K, Kakita K, Fukuma S. Large, benign osteoblastoma of the temporal bone--case report. Neurol Med Chir (Tokyo) 1989;29:444-8.

14. Jaswal A, Jana AK, Sikder B, Jana U, Nandi TK. Benign osteoblastoma of maxillary sinus: A rare presentation. Indian J Otolaryngol Head Neck Surg 2007;59:80-2. 